\title{
A rare seen pathogen in complicated skin-soft tissue infection: Pasteurella bettyae
}

\section{Komplike cilt-yumuşak doku enfeksiyonunda nadir görülen bir etken: Pasteurella bettyae}

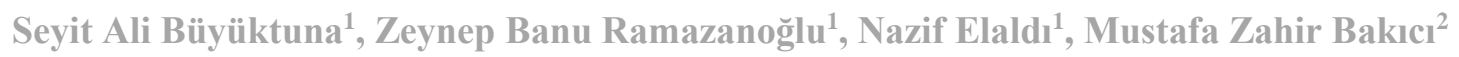

${ }^{1}$ Department of Infectious Disease and Clinical Microbiology, Faculty of Medicine, Cumhuriyet University, Sivas, Turkey

${ }^{2}$ Department of Medical Microbiology, Faculty of Medicine, Cumhuriyet University, Sivas, Turkey

Corresponding author: Seyit Ali Büyüktuna, Department of Infectious Disease and Clinical Microbiology, Faculty of Medicine, Cumhuriyet University, Sivas, Turkey

E-mail: alibuyuktuna@gmail.com

Received/Accepted: October 14, 2017 / November 06, 2017

Conflict of interest: There is not a conflict of interest.

\section{SUMMARY}

In this artice, a case of complicated soft tissue infection by Pasteurella bettyae in a patient was presented in the light of literature. $P$. bettyae has been isolated from human Bartholin gland abscesses and human finger infections as well as it was isolated from urine, gastric aspirate and urethral discharge. Soft tissue infection caused by $P$. bettyae are uncommon. To the best our knowledge, this is the first case to report the low extremity soft tissue infection caused by $P$. bettyae.

Keywords: Pasteurella bettyae, soft tissue infection, MALDI-TOF MS

ÖZET

Bu yazıda Pasteurella bettyae'nin neden olduğu komplike yumuşak doku enfeksiyonu bulunan bir hastaya ait bulgular literatür ışı̆̆ında tartışılarak sunulmuştur. P. bettyae bartholin bezi apsesi ve parmak enfeksiyonlarının yanında idrar, gastrik aspirat, ve üretral akıntıdan izole edilmiştir. $P$. bettya 'nin neden olduğu yumuşak doku enfeksiyonları çok yaygın değildir. Bizim bilgilerimize göre bu olgu sunumu $P$. bettyae ’ye bağlı alt ekstremitede yumuşak doku enfeksiyonunun bildirildiği ilk olgudur.

Anahtar sözcükler: Pasteurella bettyae, yumuşak doku enfeksiyonu, MALDI-TOF MS

\section{INTRODUCTION}

Pasteurella bettyae is a gram-negative bacilli and coccobacilli micro-organism isolated mainly in the genitourinary tract and associated samples (vaginal-cervical, urethral secretion, Bartholin Gland and amniotic fluid). It is classified under the group HB-5 according to the Centre for Disease Control and Prevention (CDC) in the United States of America. It is diagnosed as a bacteria degrading nitrate to nitrite, indole positive, lactose negative and generally as catalase negative ${ }^{1 .}$ Complicated skin and soft tissue infections caused by another Pasteurella subspecies Pasteurella multicoda have often been reported ${ }^{2}$. However, to the best of our knowledge, there have been no previous reports in literature of complicated skin soft tissue infections caused by $P$. bettyae. The case is here presented of a diabetic patient with complicated soft-tissue infection in the lower extremities, and $P$. bettyae was isolated as the pathogen microorganism. 


\section{CASE REPORT}

A 60-year old male patient, employed as a civil servant, presented at the Emergency Dept with symptoms of erythema, increased local temperature, swelling and pain covering the whole of the right knee extending towards the proximal third of the tibia (Figure 1). The patient reported a trauma history of having struck his knee on a rock in a fall and there had been contusion and a scratch on his right leg close to the knee. One day after the trauma, the patient experienced cold shivers with temperature close to $39^{\circ} \mathrm{C}$ and the abovementioned local symptoms developed. From the anamnesis taken from the patient it was learned that he was not using any antibiotics for his symptoms. There was a 10 -year history of diabetes mellitus with blood sugar level regulated by insulin.

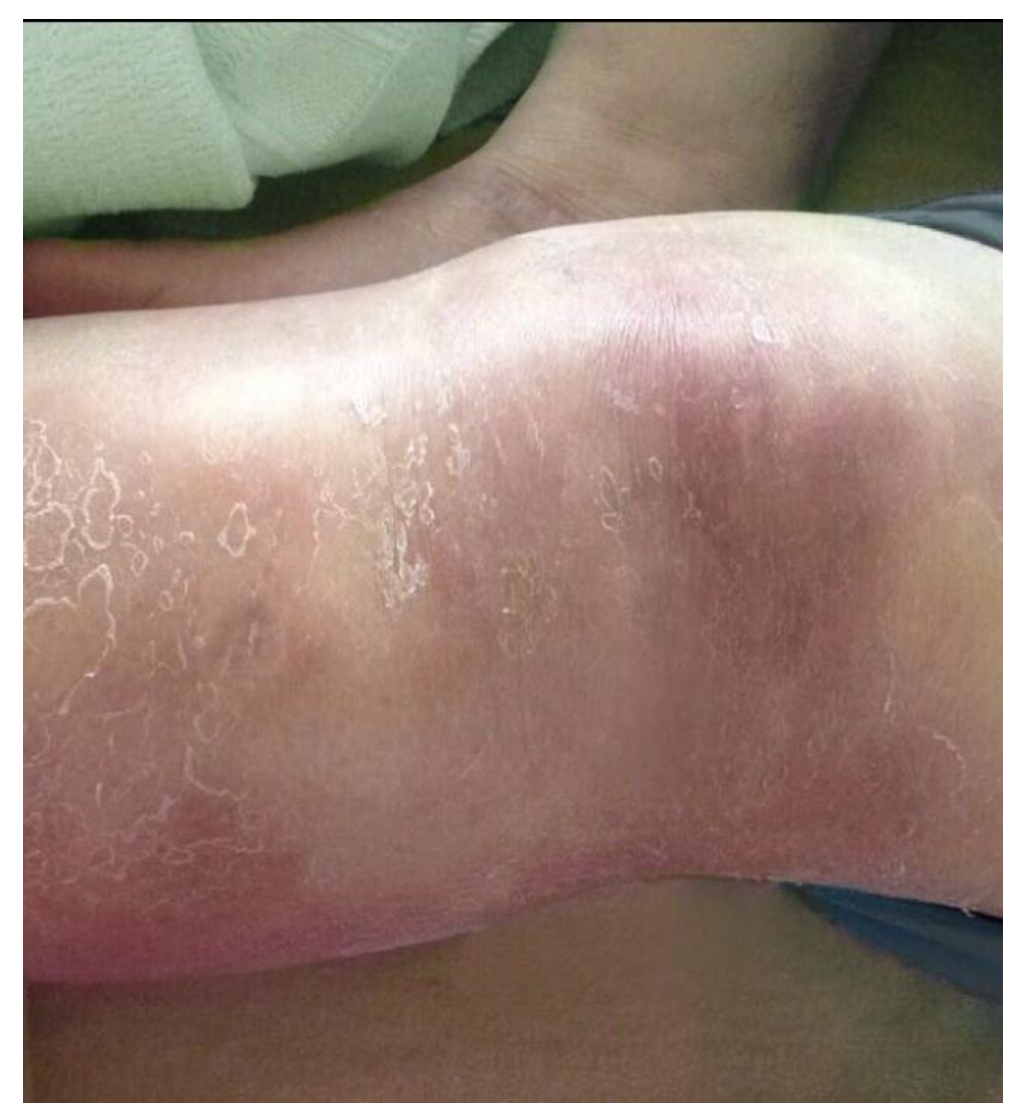

Figure 1. The erythematous lesion on leg towards $1 / 3$ tibia proximal area

In the physical examination, the general status of the patient was mediocre. He was conscious, cooperative, oriented and body temperature was tympanic $39^{\circ} \mathrm{C}$. There was seen to be erythema, increased localised temperature and oedema covering the right knee towards the anterior tibia area. Pain was observed to increase with weightbearing on the joint and passive exercise. No pathology was determined in the other system examinations. With the consideration of complicated skin soft tissue infection with septic arthritis as a pre-diagnosis, a puncture was applied to the knee joint of the patient. The results of the puncture showed leukocyte $90 / \mathrm{mm} 3$ and erythrocyte $2500 / \mathrm{mm} 3$. No micro-organism was observed in the gram staining and there was no growth in the synovial fluid culture. Within the material taken by aspiration from the swollen subcutaneous area around the patient's knee, bipolar staining gram negative coccobacillis with leukocyte was observed. With these findings, the patient was hospitalized in the Infectious Diseases Clinic with a diagnosis of complicated skin soft tissue disease (diabetic extremity).

In the laboratory examinations, WBC was $14,900 / \mathrm{mm}$ (reference value [RV] 400011000/mm3 neutrophil 83\%), haemoglobin 14. 2 $\mathrm{g} / \mathrm{dl}$ (RV: $14-18 \mathrm{~g} / \mathrm{dl}$ ), thrombocyte $368,000 / \mathrm{mm} 3$ (RV: 150,000-400,000/mm3). C-Reactive protein (CRP) $204 \mathrm{mg} / \mathrm{l}$ (RV:0-8 mg/l), and ESR 84 $\mathrm{mm} /$ hour. In the biochemical tests, blood glucose 
was $349 \mathrm{mg} / \mathrm{dl}(74-106 \mathrm{mg} / \mathrm{dl})$ and all other biomedical values were normal. In the direct radiographic comparison of both tibias and knee joints no pathological findings were identified besides soft tissue oedema.

Piperacillin - tazobactam was applied as initial therapy with a diagnosis of complicated skin soft tissue infection. There was no growth in blood cultures taken at the time of admission. $P$. bettyae had been isolated from abscess material around the right knee via Matrix-Assisted Laser Desorption/ Ionization Time of Flight Mass Spectrometry
(MALDI-TOF MS) (Bruker, Billericay, USA) (Figure 2). The patient was therefore questioned about previous interactions with animals including bites and scratches. As no antimicrobial sensitivity test according to the national and international laboratory standards [EUCAST (The European Committee on Antimicrobial Susceptibility Testing) / CLSI (Clinical and Laboratory Standards Institute)] had been applied for the micro-organism produced, the treatment was changed to ampicillinsulbactam, as ampicillin is one of the best options for the treatment of the Pasteurella group.

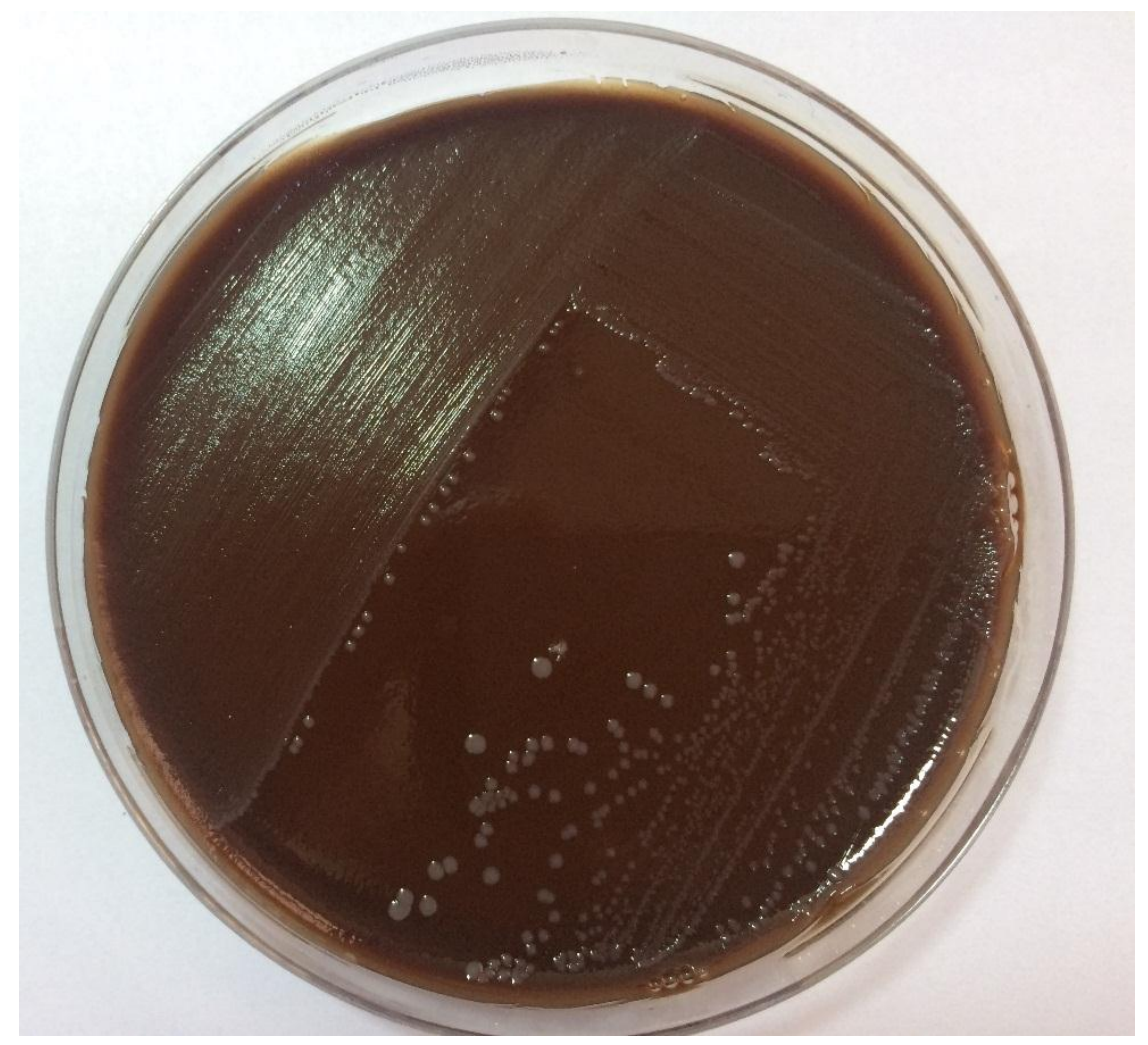

Figure 2. A representation of Pasteurella bettyae in chocolate agar

The patient was followed up with anti-bio therapy with frequent incisions made by the plastic surgery clinic. The body temperature returned to normal on the $4^{\text {th }}$ day of treatment. Blood glucose levels were checked in the clinical follow-ups, oedema, erythema and flux in the right leg decreased and the pain symptom in the right knee disappeared. The treatment was completed in 14 days and the patient was discharged from the hospital.

\section{DISCUSSION}

Pasteurella species, which are present in the normal oral and gastrointestinal system flora of many animals, are gram-negative staining coccobacilli, which grow under facultative anaerobic conditions or aerobically on bloody agar at $37^{\circ} \mathrm{C}$. Bacteria usually cause a local infection after reproducing in an insertion site. Local infections develop within 24-48 hours of exposure and generate a clinical table diagnosed as serohemorrhagic flux ${ }^{3}$.

Most of the Pasteurella infection cases reported in humans are soft tissue infections and have been caused by $P$. multocida. Clinically, this causes cellulitis and occasional subcutaneous abscess and in rare cases may progress to arthritis, pneumonia and sepsis ${ }^{2,3}$. In the current case, $P$. bettyae was identified as the pathogen micro-organism growing in the culture, although this is mostly isolated from the genitourinary system and associated samples. Clinical syndromes caused by $P$. bettyae include Bartholin abscess, peripartum bacteremia, genital ulcer and pelvic inflammatory disease (PID) ${ }^{4}$. In 
a study by Moritz et al ${ }^{\mathbf{5}}$, apart from genito-urinary infection, $P$. bettyae was determined as the pleuropneumonia agent in an HIV-1 positive patient. In another report, the micro-organism found in the blood culture of a Haitian female with peripartum bacteremia was identified as $P$. bettyae by the Massachusetts Public Health Laboratory Institute ${ }^{\mathbf{1}}$. In a study of a neonatal case of septicaemia/meningitis by De Leon et $\mathrm{al}^{6}$, it was reported that $P$. bettyae was an uncommon cause of neonatal infection.

Within the database searches conducted by entering the name of the microorganism in the accessible international and national databases (PubMed, Google Scholar, and Ulakbim), there were found to be no reports of skin and soft tissue infection related to $P$. bettyae progressing as extremity involvement.

Infections observed on humans related to the Pasteurella family have mostly developed after bites and scratches from dogs and cats. Nevertheless, infections can occur without exposure to animals or known animal interactions 7. Anatomically skin soft tissue infection most commonly occurs on the upper and lower extremities, head, face and chin as a result of bites and scratches. In the current patient, that the infection was on the lower extremity is also important as it did not occur in the urogenital localization where the cases are most common, and there was no animal interaction.

Clinical experience and studies have shown that penicillin $\mathrm{G}$ and penicillin $\mathrm{V}$, ampicillin, amoxicillin-clavulonic acid are the best options as anti-microbiological agents. Many cephalosporin have been observed to be active in $P$. multicoda infections as in-vitro. As alternative options, fluoroquinolones and doxycycline or trimethoprim-sulfamethoxazole can be considered especially in B-lactam intolerant cases ${ }^{8}$. In the current case as the patient had comorbid diabetes mellitus, which is considered to be an immune system suppressing disease, piperacillintazobactam was applied as empirical treatment. In the subsequent process, no systemic infection findings were observed and as the pathogen microorganism was sensitive, the empirical antibiotic treatment was changed to ampicillin- sulbactam.
In conclusion, this case of soft tissue infection caused by $P$. bettyae in a diabetic patient underlines the necessity for microbiological examinations to diagnose the pathogen and is a reminder that different micro-organisms can cause skin soft tissue infections especially in patients with an underlying immune-suppressing disease such as diabetes mellitus.

\section{REFERENCES}

1. Shapiro DS, Brooks PE, Coffey DM, Browne KF. Peripartum Bacteremia with CDC Group HB5 (Pasteurella bettyae). Clinical Infectious Diseases 1996; 22: 1125-6

2. Ceyhan AM, Kaya O, Başoğlu N, Tiğlı A, Yıldırım M. Pasteurella Multocida'nın Neden Olduğu Nadir Görülen Nekrotizan Yumuşak Doku Enfeksiyonu Olgusu. Turkiye Klinikleri J.Med.Sci 2010; 30.

3. Topçu AW, Söyletir G, Doğanay M. Enfeksiyon Hastalıkları ve Klinik Mikrobiyolojisi, 3. Baskı. Nobel Tip Kitabevi 2008: 2249-51.

4. Koneman EW, Allen SD, Janda WM, Schreckenberger PC, Winn WC. Color Atlas and Textbook of Diagnostic Microbiology, 5 th Ed. Lippincott Williams Q Wilkins.1997: 395-472

5. Moritz F, Martin E, Lemeland JF, Bonmarchand G, Leroy J, Escande F. Fatal Pasteurella bettyae Pleuropneumonia in a Patient Infected with Human Immunodeficiency Virus. Clin Infect Dis 1996; 22: 591-2.

6. De Leon JP, Sandfort RF, Wong JD. Pasteurella bettyae: Report of nine cases and evidence of an emerging neonatal pathogen Clinical Microbiology Newsletter, 2000.

7. Zurlo JJ. Pasteurella species. In: Mandell GL, Benett JE, Dolin Reds. Principles and practise of infectious diseases, 7thed. Philadelphia: Churchill Livingstone.2010:2939-42

8. Goldstein EJC, Citron DM, Richwald GA. Lack of in vitro efficacy of oral forms of certain cephalosporins, erythromycin, and oxacillin against Pasteurella multicida. Antimicrob. Agents Chemother 1988; 32: 213-25. 